\title{
Komedi Filmlerinde Siiddetin Sunumu: Türkiye'de En Çok İzlenen Komedi Filmleri Üzerine İçerik Analizi
}

\author{
Nermin ORTA ${ }^{12}$
}

Öz

İnsanlığın başlangıcından beri her daim var olan şiddet, anlamı genişleyerek, günümüze dek gelmiştir. Anlatıların da bir parçası olan şiddet, mitolojiden sinemaya pek çok sanat eseri içinde hikayenin önemli bir unsuru olarak işlev görmüştür. Komedi türü gibi en çok izlenen türler arasında yer alan ve bireyleri eğlendirmeye yönelik filmler içinde de şiddet öğeleri sıklıkla karşımıza çıkmaktadır. Türkiye'de komedi filmlerişiddet ilişkisini ve komedi filmlerinin şiddet unsurlarını ne oranda perdeye yansıttığını ortaya koymak amacıyla yapılan bu çalışmada içerik analizi yöntemi kullanıımıştır. En çok izleyici sayısına ulaşan ilk 20 film içindeki komedi filmleri araştırmanın örneklemini oluşturmuştur. Filmlerde şiddete yer verilip verilmediği, şiddetin kaynağı, cinsiyete göre dağılımı, şiddetin türü, ekrana nasıl yansıdığı gibi unsurlara cevap aranmış, ardından filmin içeriği ve şiddetin işlevi filmler üzerinden değerlendirilmiştir. Sonuçta komedi filmlerinin büyük bir kısmında diğer türlerde olduğundan çok daha fazla şiddet öğesinin yer aldığı ve bunların birer mizah unsuru olarak sunulup, şiddetin gerçek sonuçlarından uzak bir şekilde temsil edildiği tespit edilmiştir.

Anahtar Kelimeler: Şiddet, Komedi Filmleri, Türk Sineması. 


\title{
Representation of Violence in Comedy Movies: Content Analysis of Most Watched Comedy Films in Turkey
}

\begin{abstract}
Violence, which has always existed since the beginning of humanity, has come to the present day by expanding meaning. Violence, which is also a part of the narratives, has served as an important element of the story in many works of art, from mythology to cinema. Among the most watched genres such as the comedy and the films aimed at entertaining individuals, violent elements are frequently encountered. In this study, content analysis method was employed to reveal the relationship between violence and the comedy films made in Turkey and the percentage of the violent elements reflected to in each film. The comedy films among the first 20 films that reached the highest number of viewers were selected as a sample. The films were examined based on whether or not violence was included in these films, the source of the violence, the distribution according to gender, the type of violence and how it was reflected on the screen. Then, the content and the function of the violence were evaluated through the films. As a result, it has been found that most of the comedy films contain more elements of violence than the other genres and these are presented as humor elements without showing real consequences of violence.
\end{abstract}

Keywords: Violence, Comedy Films, Turkish Cinema.

\section{Giriș}

iddet insanlık tarihi kadar eski bir olgu olup değişim ve dönüşümlerle her
dönemde ve her toplumda farklı şekillerde ortaya çıkmıştır. Bu bağlamda kültürle
3 doğrudan ilişkili olan şiddet tanımı da toplumdan topluma farklılık göstermiştir. Dünya Sağlık Örgütü şiddeti, "Kendine, diğer bireye veya bir grup ya da topluluğa karşı kasıtlı olarak, tehdit veya fiilen yaralama, ölüm, psikolojik zarar verme, engelleme veya yoksun bırakma ile sonuçlanan fiziksel güç kullanılması" olarak tanımlamıştır (https:// www.who.int,4).

Bu tanımdan yola çıkarak şiddet; bir kişiye, gruba, topluluğa yönelik zarar vermeyi amaçlayan fiziksel ya da duygusal bir eylem olmanın yanında, sözel saldırı, baskı uygulama, engelleme ve maddi manevi zarar verme olarak değerlendirilebilir. Bu anlamda şiddet fiziksel saldırıların yanı sıra, sözlü ve psikolojik her türlü baskıyı da kapsamaktadır (Mutlu, 1997, s.55).

Ünsal (2007, s.31-33) ise şiddeti dar ve geniş anlamları açısından incelemektedir. Dar anlamıyla şiddet; fiziksel şiddeti çağrıştırmaktadır ve insanların bedensel bütünlüğüne karşı yöneltilen, sert ve acı verici bir edimdir. Geniş anlamda şiddet ise; dolaylı şiddet olarak kabul edilebilecek insan üzerindeki fiziksel ve ruhsal etkileri açıkça ölçülemeyen, çeşitli soyut baskılardır. Örneğin ekonomik şiddet, medya terörü, enflasyon, işsizlik, trafik korsanlığı, doğanın ve tarihsel çevrenin tahribi, sağlıksız kentleşme gibi olgular 
şiddetin geniş kapsamlı tanımı içine dahil edilebilmektedir. Ünsal'ın yapmış olduğu bu değerlendirme şiddeti çok daha kapsamlı olarak ele almakta ve günlük hayat içinde sıklıkla karşılaşılan pek çok eylemi de içine almaktadır.

Şiddetin hayatın bu derece içine girmesi anlatıları da etkilemekte ve geçmişten günümüzde pek çok tür içinde karşımıza çıkmaktadır. Mitolojiden sinemaya dek anlatı içinde kimi zaman örtük kimi zaman açık bir şekilde ve farklı türleriyle sunulan şiddet genellikle dramatik etkiyi artırmak ve anlatıyı gerçekçiliğe yaklaştırmak için kullanılmaktadır. Aksiyon-macera, western, savaş, dram filmlerinin vazgeçilmez unsurlarından biri olan şiddet öğeleri sadece bu filmlerle sınırlı kalmamakta özellikle kavramın geniş kapsamlı tanımında yer alan boyutları melodramdan komedi filmlerine kadar her tür içinde geniş yer bulmaktadır. İlk örneklerde açıkça görülen bu unsurlar, komedi filmleri gibi bireyi eğlendirmeye yönelik türlerde hikaye içinde mizah öğesi haline getirilmekte ve özellikle sözlü ve duygusal şiddetin hemen hemen tüm şekilleri filmler içinde yer almaktadır. Komedi filmlerinde karikatürize edilen ve kimi zaman filmin kahramanının temel karakteristik özelliği haline gelen şiddet göstergeleri bu bağlamda üzerinde tartışılması gereken önemli bir unsur olarak karşımıza çıkmaktadır. Türkiye'de en çok izlenen ilk 20 filme bakıldığında ağırlık olarak komedi filmlerinin yer aldığı görülmektedir. İlk 20 film içerisinde kurmaca film kategorisine giren 12 film komedi türündedir. Türkiye'de komedi filmleri-şiddet olgusu ilişkisini ve komedi filmlerinin şiddet unsurlarını ne oranda perdeye yansıttığını ortaya koymak amacıyla yapılan bu çalışmada, 12 film üzerinden değerlendirme yapılacaktır. Öncelikle şiddet, şiddetin türleri ve sinema şiddet ilişkisi teorik bir çerçevede tartışılacak, ardından içerik analizi yöntemi ile filmler değerlendirilecektir. Filmlerde şiddete yer verilip verilmediği, şiddetin filmdeki işlevi ayrıntılı olarak ele alınacaktır. Yukarıda da belirtildiği gibi şiddet iletişim bilimleri de dahil pek çok farklı disiplinin ele aldığı bir kavramdır. Ancak özellikle 1990 sonrası yükselişe geçen ve yabancı filmlere göre gişede büyük başarılar kazanan ve izleyici rekorları kıran Türk komedi filmleri özelinde sinema-şiddet ilişkisi ele alınmayan bir konu olarak dikkat çekmektedir. Bu çalışma en çok izleyici sayısına ulaşan 20 film içinden komedi filmlerini ele alıp incelemeye tabi tutması açısından diğer çalışmalardan farklıdır.

\section{1. Șiddet ve Șiddet Türleri}

Şiddet kavramı ve şiddet türleri pek çok yazar tarafından ele alınmış ve farklı farklı şekillerde sınıflandırılmıştır. Fromm, insanın doğuştan yok etme eğilimi taşıdığını vurgulamış, şiddetin çeşitli türleri arasındaki ayırımın, değişik, bilinçsiz dürtüler arasındaki ayırımdan doğduğunu dile getirmiştir (Fromm, 1994, s.20). Fromm şiddeti oyun içinde ortaya çıkan, tepkisel, öç alıcı, ödünleyici şiddet ve kana susamışlık olarak sınıflandırırken (Fromm, 1994, s.20-30), Dünya Sağlık Örgütü 2002 yılında yayınladığı şiddet raporunda şiddeti, kendine yöneltilmiş, kişilerarası ve kolektif olmak üzere üç ana başlıkta toplamıştır (http://www.who.int).

Şiddetin geniş ve dar kapsamlı tanımını yapan Ünsal ise Chenais'in sınıflandırmasından yola çıkarak, şiddeti ilk olarak özel ve kolektif olarak ikiye ayırdıktan sonra bu iki türü 
kendi içinde türlere ayırmıştır (2007, s.35).

Şiddet biçimlerinin en yaygın olarak kullanılan sınıflandırması ise genel olarak fiziksel, duygusal, cinsel, ekonomik, sözel ve simgesel şiddet şeklindedir.

Temeli güç, kaba kuvvet ve zor kullanmaya dayanan fiziksel şiddette amaç olarak, zarar vermek ve/veya varlığının bütünlüğünü ortadan kaldırmak bulunmaktadır. (Ünsal, 2007, s.31- 32). Bu anlamda fiziksel şiddet, vurmak, tekme, işkence yapmak, yaralamak, sakat bırakmak, bireyin bedensel zarar görmesine neden olmak, öldürmeye çalışmak ya da öldürmek gibi eylemleri kapsamaktadır.

Sözel şiddet ise, kötü niyetli söz eylemlerinden, başkasına zarar vermek ya da öç almak için dile getirilen ifadelerden oluşmaktadır (Karabağ, 2010, s.21). Bir kişinin karşısındakine küçük düşürücü, rencide edici sözler söylemesi, hakkında dedikodu yapması, iftira atması ya da tehdit edici söylemlerde bulunması sözlü şiddet olarak değerlendirilmektedir.

Duygusal şiddet ise bireylerin psikolojisini olumsuz etkileyen, kişinin kendisini baskı ve tehdit altında hissetmesine neden olan her türlü tutumu ifade etmektedir. Duygusal şiddet, kişinin benliğine zarar vermeyi, onu korkutarak güçsüz ve aciz hissetmesine neden olup kontrol altına almayı amaçlamaktadır. Sık karşılaşılan bir şiddet biçimi olmasına rağmen fiziksel şiddet gibi anlamlandırılması ve anlaşılması kolay değildir. Çoğu durumda gözle görülür olmadığı için süreklilik kazanmakta ve kabul edilmesi kolaylaşmakta, şiddete maruz kalan birey bu durumu içselleştirmekte, bunu normal olarak görmekte ya da kendisini suçlu şekilde algılamaktadır (Coker vd 2000; Retzinger, 1991; Jackson vd, 2000).

Bir diğer psikolojik şiddet biçimi de mobbingdir. Mobbing, bir veya birkaç kişi tarafından diğer bir kişiye yönelik olarak, sistemli bir şekilde uygulanan bir psikolojik terördür. Kişiyi işyerinde, tacizkar ve kötü davranarak dışlamak veya kapasitesinin altında işler vererek onu küçük düşürmek şeklinde kendini göstermektedir (Leymann, 1990,s.120; Leymann, 1996, s.167-168).

Ekonomik şiddet ise, ekonomik kaynakların kişiler üzerinde bir yaptırım, iktidar ya da tehdit aracı olarak kullanılmasıdır. Çoğu zaman duygusal ve/veya cinsel şiddetle birlikte yaşanıyor olması genellikle bu şiddet türünün farkedilmesini engellemektedir. Aile içinde eşin ya da çocuğunun parasını almak ve geri vermemek, zorla istemediği bir işte çalıştırmak ya da çalıştırmamak, hiç para vermemek, sağlık hizmetlerinden yararlanmasını engelleme, çalışmayı reddedip, kişinin (kadının) gelirini harcama gibi durumları içerir (Casique ve Furegato 2006, s.953; Köse ve Beşer 2007, s.117). Mobing de iş yerinde ortaya çıktığı ve ekonomik kaynak temelli olduğu için aynı zamanda ekonomik şiddetin de bir alt türü olarak kabul edilebilmektedir.

Diğer bir şiddet türü olan cinsel şiddet; bireylere yönelik olarak laf atma davranışından başlayıp tecavüze kadar varan geniş bir yelpazede gerçekleşen cinsel taciz ve saldırıdır. Burada esas olan cinselliğin bir tehdit, sindirme ve kontrol etme aracı olarak kullanılması ve kimi durumlarda güç-iktidar göstergesine dönüşmesidir. El şakaları, dokunma, öpme, sarılma ve tecavüz gibi davranışları bu şiddet türü arasında yer almaktadır. Bu tür davranışlar kimi zaman aile dışından bir çocuğa, kadına, erkeğe 
olabileceği gibi kimi zamanda aile içinde ve akrabalık ilişkisi olan bireyler tarafından da uygulanabilmektedir (Orta, 2016, s.51-52).

Son şiddet türü olan simgesel şiddette, ona maruz kalanlar ile aynı zamanda da çoğu kez onu uygulayanların sessiz suç ortaklığı söz konusudur. Bourdieu'nun ifadesiyle simgesel şiddet, "toplumsal eyleyici üzerinde kendi suç ortaklığıyla uygulanan şiddet biçimidir." (Bourdieu, 2003,s.166). Kavram tanımı gereği "bireyleri (kısmen kendi rızalarını da kuşatarak) sınırlama, belirleme ve çeşitli kategorilere ayırıp bir düzene koyma gibi içeriklere sahiptir." (Özsöz, 2014, s.290) Bu şiddet türü zihinsel etki amacına yönelik şiddettir.

Simgesel şiddetin kendini var ettiği alanlar içerisinde en önemlisi kitle iletişim araçları ürünleridir. Görsel, işitsel ve yazılı medyanın bireyi ve toplumu kapsamına alması, korku ve şiddete bürünmüş bir dünya propagandası yapması bireyin zihninde kodlamalar oluşturmakta ve çağrışım yaratmaktadır. Haberlerde, dizilerde ve filmlerde tanık olduğumuz şiddet hem bizdeki şiddet kodunu harekete geçirip şiddeti tekrar deneyimlememizi sağlarken hem de yeni, alışık olmadığımız şiddet edimlerini göstererek yeni şiddet kodlarını alımlamamızı sağlamaktadır (Aydın, 2012, s.4-5). Bu anlamda izleyicilerin sinema filmlerinde maruz kaldığı şiddet simgesel şiddet biçimi içinde değerlendirilmektedir.

\section{Sinema Șiddet Ilișkisi Üzerine}

Şiddet her dönem anlatının bir parçası olmuş ve çoğu zaman mitoloji, edebiyat, resim, tiyatro ve sinema gibi sanat eserleri içinde hikayenin önemli bir unsuru olarak işlev görmüştür. Anlatı içinde kimi zaman örtük kimi zaman açık bir şekilde ve farklı türleriyle sunulan şiddet genellikle dramatik etkiyi artırmak ve anlatıyı gerçekçiliğe yaklaştırmak için kullanılmaktadır.

Ryan ve Kellner'a göre, filmler, herhangi bir durumu yansıtmaktan çok temsili öğeler yoluyla birtakım tezler ileri sürmekte ve seyirciye belli bir konumu ya da bakış açısını telkin etmektedirler. Anlatının kapanma tarzı, görüntünün sürekliliği, karakter özdeşleştirmesi, nedensellik mantığı vb biçimsel görenekler de, sinemanın yapaylığına ilişkin işaretleri ortadan kaldırarak bu konumlamanın içselleştirilmesine katkıda bulunmaktadır. Bu yolla, eril kahramanlık serüvenleri, romantizm arayışı, kurtarıcı şiddet öyküleri, ırkçılığa ve suça ilişkin bir takım tematik öğeler, dünyanın doğal ve açık göstergeleri olarak algılanmasını sağlamaktadır. Böylece seyirci belli bir toplumsal düzenin temel varsayımlarını benimsemeye ve bunların içerdiği akıldışılık ve adaletsizlikleri göz ardı etmeye alıştııılır (1997,s.18).

Yani genel olarak öykülendirmede egemen değer ve görüşlerin sunumu ve özel olarak şiddetin öykülendirilmesindeki her söz ve düşünce toplum içinde eşitsiz ilişkilerin pekiştirilmesine hizmet edebilmektedir (Aziz vd. 1993, s.17). Bu noktada şiddetin anlatı içindeki yeri ve nasıl sunulduğu önem kazanmaktadır.

Sinema tarihine bakıldığında şiddet unsurunun kullanımının ilk filmlere kadar uzandığı görülmektedir. George Melies'in Aya Yolculuk (1902) filmi şiddet görüntülerin kullanıldığı 
ilk filmler arasında yer almaktadır. Zamanla konulu filmlerin artması ve teknolojinin gelişmesiyle sinemada şiddetin sunumu da bu gelişmeye paralellik göstermiştir. Sinemaya sesin gelmesiyle filmlerin etkisini artırmak amacıyla filmlere müzikler ve efektler eklenmiş, özellikle savaş sahneleri içeren filmlerle şiddetin gösterimi de artmıştır.

Sinema-şiddet ilişkisi düşünüldüğünde Gerbner'ın ortaya koyduğu "mutlu şiddet" kavramı dikkat çekicidir. Peri masallarından, mitolojiye ya da Shakespeare hikayelerine kadar hemen her anlatı içinde yer alan şiddet trajik sonları dengelemek için kültürel temsiller yoluyla meşrulaştırılmaktadır. Bu "mutlu şiddet" hızı, havalı, heyecan verici, acısız, etkili ve izleyicinin keyfini kaçırmayacak şekilde dizayn edilmiş, mutlu sonu beraberinde getirmiştir (Gerbner vd, 1999, s.344). Yani şiddet, gerçek şiddetin karakteristiği olan, acı ve ceza çekme unsurları olmaksızın gösterilmekte ve bu sahneler sterilleştirilerek şiddet daha kabul edilebilir hale gelmektedir. Filmlerde tüm problemler şiddet ile çözülebilmekte ve şiddetin ciddi sonuçları ortaya çıkmamaktadır. (Stossel, 1997, s.18). Dolayısıyla bireylerin şiddetle olan mesafesi azalmaktadır.

Gösterilen şiddetin cezasız kalması ya da meşrulaştırılarak hayatın bir gerçeği, sıradan bir olay olarak sunulması izleyicilerin algısı üzerinde etkili olmakta ve anlatı içinde kabul edilebilir hale gelen bu durum gerçek hayatta ki kabullenmeyi de beraberinde getirebilmektedir.

Çoğunlukla geleneksel ahlak anlayışını destekleyecek şekilde çözümlenen ve çatışmalar, acı çekmeler, kötülükler, dalaverelerle ilerleyen melodramlarda dahi ağırık, şiddet ve seks üzerinde toplanmakta, iyi ile kötü arasında yoğun bir çatışma yaşanmaktadır. İyi ve ahlaklının kazanması, düzenin yeniden kurulmasıyla sonuçlanan bu anlatılar sistemin de yeniden üretimini ve devamını sağlamaktadır (Alemdar ve Erdoğan, 1994, s.130-131).

Türk sineması-şiddet ilişkisine bakıldığında farklı bir tablo ile karşılaşılmamaktadır. İlk konulu Türk filmi olarak kabul edilen 1917 yılında Sedat Simavi'nin çektiği Pençe filminden itibaren Türk sinemasında şiddet sahneleri yer almıştır. Türk sinema tarihinin en çok konuşulan, film üretimi ve seyirci sayıları açısından rekorların kırıldığı Yeşilçam sinemasının vazgeçilmez unsurları arasında yine şiddet yer almaktadır. Yeşilçam'ın temelini oluşturan melodramda da sanıldığının aksine yoğun olarak şiddet kullanılmaktadır. Bu tür içinde fiziksel, sözel, psikolojik, ekonomik şiddet ve cinsel şiddet sıklıkla yer almaktadır. Nilgün Abisel'in 1998 yılında 103 filmi örneklem olarak aldığı ve Yeşilçam filmlerinde ki kadının konumu ve şiddet üzerine yaptığı araştırma, özelde kadınlara yönelik fiziki şiddet ve şiddet kullanma tehdidini ele almış olmasına rağmen, "Yeşilçam filmlerinde sıklıkla herkese karşı doğrudan kaba kuvvet kullanıldığını çünkü inşa edilen kurmaca dünyalarda şiddetin sorgulanmaksızın, yaşamsal gerçekliğin ayrılmaz bir parçası olarak yer aldığını" vurgulamaktadır. Bu filmlerde kadına yönelik şiddetin yanı sıra erkekler arası şiddet çoğu kez kadınların varlığından kaynaklanmakta, büyük oranda yarışmacı bir nitelik taşımakta ve geleneksel erkek iktidarının düşünce ve davranış kodlarıyla açıklanabilmektedir (2005, s.312-313).

80'li yılların sonlarından itibaren çekilmeye başlanan ve darbeyi bireysel hikayeler üzerinden anlatan ve işkence görmüş kişilerin yaşamlarına odaklanan filmlerde 
şiddetin farklı türleri ortaya konmuştur. Kimi zaman görüntü ve sesle birlikte verilen bu sahneler, kimi zaman sadece işitsel olarak yansıtılmakta, kimi zaman da mağdurların anlattıkları ile perdeye yansımaktadır.

90’lı yıllardan itibaren Türk sineması iki ayrı kulvarda ele alınmaya başlanmıştır. Genel olarak popüler ve bağımsız sinema başlıklarında yapılan bu ayrım pek çok konunun iki türde farklı farklı ele alınmasından ve sinema dili anlayışından kaynaklanmaktadır. Pek çok açıdan farklılık gösteren bu iki sinema anlayışının şiddet ve sunumu konusunda da farklılıklar gösterdiği görülmektedir.

Bağımsız sinema- şiddet olgusu ele alındığında pek çok yönetmenin özellikle metropollerde yaşanan şiddete ilişkin hikayeleri perdeye yansıttıkları görülmektedir. Gemide (1998, Serdar Akar³), Düş Gezginleri (1992, Atıf Yılmaz), Aşk Ölümden Soğuktur (1994, Canan Gerede), Karartma Geceleri (1990, Yusuf Kurçenli), Tabutta Rövaşata (1996, Derviş Zaim), Karışık Pizza (1998, Umur Turagay), Dokuz (2001, Ümit Ünal), 3. Sayfa (1999, Zeki Demirkubuz), Duvara Karşı (Fatih Akın, 2004), İki Kadın (1992, Yavuz Özkan), İklimler gibi pek çok filmde şiddetin farklı türlerine rastlanmaktadır. Hayatın bir parçası olan ve özellikle de yönetmenlerin gerçeklik algısını en üst seviyeye çıkarmak ve hayattın gerçeklerinden hikayeler anlattıklarını ortaya koyabilmek adına sıklıkla yer verdikleri şiddet sahneleri bağımsız yapımlar için de sıklıkla eleştiri konusu olmuştur.

Baudrillard (2004: s.226-227), gelişmiş ya da aşırı gelişmiş ülkelerin toplumlarındaki şiddeti, bolluğun temel çelişkilerinde görmekte ve şiddetin nedenlerini, "Söz konusu olan belli bir eşiğe ulaştığında bolluğun ve güvenliğin doğurduğu gerçek, denetlenmez şiddet sorunudur. Bu artık başka bir şeyle bütünleşen, tüketilen şiddet değil, ama refahın kendi gerçekleşmesinde doğurduğu denetlenemez şiddettir. Bu şiddet (tam olarak yapay anlamında değil, bizim tanımladığımız biçimiyle) amaçsız ve nesnesiz olmasıyla belirlenir." şeklinde açıklamaktadır.

Pişkin de "Hızıı ve Dengesiz Değişime Tepki Olarak Sinemada Şiddet: Türkiye Örneği: 1980-2006" isimli çalışmasında şiddetin kökenlerini ve sinemaya olan bu yansımayı tıpkı Baudrillard gibi toplumsal gerçekler içinde aramakta ve göç-şiddet ilişkisine dikkat çekmektedir. Pişkin'e göre (2007, s.579-580), "Türkiye"de de insanlar doğduğu yerde aile kurup ölmek yerine, eğitim, iş değiştirerek yükselmek, iş bulmak, sınıf atlamak için yer değiştirmiş, yalnızlaştıkça da çevresine karşı korku geliştirmiştir. Bu yalnızlık duygusunu kitle iletişim araçlarına yönelerek gidermeye çalışmış, şiddet öykülerine merak salmıştır. Şiddet ağırlıklı popüler metinlerin içinde haklılaştırılmış şiddet unsuru vardır. ..."

Yüce (1995) ve Karayel (2007)'de göç-şiddet ilişkisi üzerinde durmuş ve problemin kökenlerinin geçmiş yıllara dayandığı ve bu durumun da sinemaya yansıdığını vurgulamışlardır.

Uyandırdığı tüm olumsuz duygulara rağmen, bir çekicilik duygusuna sahip olan ve

3 Serdar Akar'ın yönetmenliğini yaptığı Gemide ve Barda filmleri, tecavüz ve şiddet sahnelerine açıkça yer verilmekte, özellikle Barda filmi şiddetin her türünün yoğun olarak gösterildiği bir film olarak izleyici karşısına çıkmaktadır. Her iki filmde de tecavüz(ler) anlatı içinde oldukça önemli role sahiptir. 
kişinin güç ve güçlü ile özdeşleşmesini sağlayan şiddet, estetize edilerek büyüleyici ve çekici bir hale sokulabilmektedir. Sinematografik açıdan ve film atmosferini yansıtması açısından oldukça başarılı görülen ve gerçeğe oldukça yakın bir dünya görüntüsü çizen bu filmlerin şiddeti de estetikleştirerek ve yaşanan olaylar içinde kabul edilebilir bir durum olarak sunması, sıradanlaştırıp, normalleştirmesi en önemli problem olarak görülmektedir.

Popüler sinema tarafına bakıldığında da şiddet unsurlarının filmlerde sıklıkla yer aldığı görülmektedir. Popüler sinemada şiddet kimi zaman öyküyü geliştiren ve bir yere taşıyan bir unsur olmakta, kimi zaman karakteri tamamlayan bir özellik olarak yer almakta kimi zamanda mafya ilişkileri, sokak çatışmaları, milliyetçilik söylemleri, bireysel çıkarlar, sorun çözmek vb unsurlarla gelen bir olgu olarak filmlerde yer almaktadır.

Eşkıya (1996, Yavuz Turgul) , Dağ (2012, Alper Çağlar), Nefes Vatan Sağolsun (2009, Levent Semerci), Av Mevsimi (2010, Yavuz Turgul), Fetih 1453 (2012, Faruk Aksoy), Kurtlar Vadisi Irak (2006, Serdar Akar), Kabadayı (2007, Ömer Vargı) gibi gişede önemli başarılar kazanmış pek çok filmde şiddetin yoğunluklu olarak yer almaktadır. Bu filmlerin bir kısmında savaş ve çatışma sahneleri, adam öldürme, silah çekme gibi fiziksel şiddet sahneleri yoğunlukta yer alırken bir kısmında da baskı, tehdit, hakaret gibi sözel ve duygusal şiddet sahneleri yer almaktadır.

Genel bir değerlendirme yapıldığında 90'li yıllarda başlayan ve 2020'ye kadar devam eden süreç içinde sinemamızda şiddet hem popüler filmlerde hem de bağımsız filmlerde hep var olmuştur.

\subsection{Komedi Unsuru Olarak Sinemada Șiddet}

Şiddetin sıklıkla yer aldığı film türleri içerisinde korku, savaş, western, aksiyon, gerilim ve bilimkurgu ilk akla gelenler arasında yer almaktadır. Ancak şiddet içeriğinin artmasıyla diğer türlerde de şiddet öğeleri yoğun olarak kullanılmaya başlanmış, melodramlardan komedi filmlerine kadar geniş bir yelpazede hemen her türün bir parçası haline gelmiştir.

Lumiere kardeşlerin 1895 yılında çektikleri ilk filmlerden olan Bahçıvanın Sulanışı (L'arroseur Arrose) filminden itibaren komedi filmlerinde yer alan şiddet öğeleri, sinemanın en çok izlenen komedi filmleri arasında yer alan ve klasikleşmiş Charlie Chaplin filmlerinde de sıklıkla karşımıza çıkmaktadır.

Daha önce de belirttiğimiz gibi şiddet öğesi söz konusu olunca ilk akla gelen türler savaş, aksiyon macera, western olmasına rağmen Browne ve arkadaşlarının 2002 yılında Amerika'da gerçekleştirdikleri araştırma komedi filmlerinde şiddet unsurlarının ciddi oranda yer aldığını ortaya koymuştur. En çok izlenen 100 film üzerine yapılan araştırmada ele alınan 14 aksiyon filminde 658 şiddet sahnesi tespit edilirken, 41 komedi filminde 586 şiddet unsuru tespit edilmiştir. Çalışmada film başına düşen şiddet unsuru aksiyon filmlerinde daha fazla yer almasına karşın, komedi filmlerinde yer alan şiddet öğelerinin rahatsız edicilikten uzak olmasının altı çizilmiştir (Browne vd, 2002).

Zilmann komedinin küçük düşürme, hakaret, küçümseme gibi unsurları fazlasıyla 
barındırdığına dikkat çekmektedir. Wolff, Smith, Murray'in 1934 yılında psikolojik araştırmalarda ortaya koydukları "üstünlük teorisi” ya da mizahta aşağılama teorisi" çalışmalarına değinen Zilmann komedi ve mizah söz konusu olduğunda anlatı içinde "kurban" ve "kazanan" tarafın olacağına vurgu yapmakta ve bunun kazananın kurbanı aşağılaması, küçük düşürmesi ya da kendi üstünlüğünü kanıtlaması ile gerçekleşeceğine dikkat çekmektedir (Zilmann, 2000, s.39-41).

McIntosh ve arkadaşlarının ortaya koyduğu çalışmada da, kimi zaman mizahın psikolojik şiddeti açıkça ortaya koyduğu ifade edilmekte ve komedi unsuru olarak sunulan şiddetin, şiddet ve mizah araştırmaları kadar yaygın olarak ele alınmadığı eleştirisi yapılmaktadırlar (2003, s.346). Bu anlamda araştırmalarda, kurban ile failin nasıl analiz edildiğini ortaya koymanın ve şiddet-komedi ikilisinin popülerliğini toplumsal bağlamla ilişkilendirmenin, komedi şiddetinin etki ve fonksiyonlarını anlamak için bir adım olduğunu belirtmişlerdir (2003, s.357). 1951-2000 yılları arasını kapsayan çalışmalarında yıllar geçtikçe komedi filmlerindeki şiddet unsurlarının arttığını ortaya koyan araştırmacılar, burada yer alan şiddetin nadiren olumsuz sonuçlarının gösterildiğine de dikkat çekmektedir (2003).

Sanatel'in de belirttiği gibi, insanlar teknolojik gelişmeyle birlikte şiddete daha çok gömülüp şiddeti kanıksamakta ve sinemanın bir kaçış sineması haline gelmesi ile birlikte şiddet eğlence aracına dönüştürülüp, tehlikeli boyutu göz ardı edilmektedir (2000, s.95).

Şiddet içerikli mizahın Anadolu kültüründe çok eskilere dayandığını belirten Ünlü, geleneksel Türk tiyatrosunda, meddah hikâyelerinde ve gölge oyunlarında şiddetin konu, kullanılan dil, davarnış gibi pek çok yolla aktarıldığına dikkat çekmekte ve Karagöz ve Hacivat karakterlerinin temelde kimlik farklılığına dayanan fiziksel ve sözel şiddet yüklü ilişkisinin bunun en güzel örneği olduğunu vurgulamaktadır (Ünlü, s.2007).

$\mathrm{Bu}$ ilişkinin sinemanın erken döneminden itibaren Türk sinemasında da anlatılara yansıdığı komedi türünün şiddet unsurlarına her dönem yer verdiği söylenebilmektedir. Şadi Karagözoğlu'nun 1917 yılında çektiği Türkiye'de sinema tarihinin ilk komedi ve ilk seri filmlerin başlangıcı olarak kabul edilen Bican Efendi Vekilharç filminden itibaren komedi filmlerinde şiddetin yer aldığı görülmektedir. Film sessiz dönem filmi olmasına karşın Bican Efendinin sakarlıkları ve fiziksel şiddet sahneleri filmin komedi unsurları olarak yer almaktadır. Sinemanın ilerleyen yıllarında Cilalı ibo (Feridun Karakaya), Turist Ömer (Sadri Alışık), Şaban (Kemal Sunal) karakterleri ile ön plana çıkan komedi filmlerinde ise gerek sözel gerekse fiziksel şiddetin yoğunluklu olarak yer aldığı görülmektedir. Bu karakterlerin başına gelen olumsuz durumlar, yaşanan sakarlıklar, kimi zaman gördükleri fiziksel ve sözel şiddet ya da bu karakterlerin sürekli küfürlü konuşmaları izleyicilerin benimsediği, normalleştirilen sıradan olaylar halinde sunulmaktadır.

Sinemanın erken dönemlerinden itibaren görülen bu birlikteliğin son dönem Türk sinemasında da belirgin biçimde devam ettiği görülmektedir. Organize Işler (2005, Yılmaz Erdoğan), Organize Işsler Sazan Sarmalı (2018, Yılmaz Erdoğan), Hababam Sınıfı Askerde (2005, Ferdi Eğilmez), Vizontele Tuuba (2004, Yılmaz Erdoğan), Kahpe Bizans (2000, Gani Müjde), Yahşi Batı (2010, Ömer Faruk Sorak), Kocan Kadar 
Konuş (2015, Kıvanç Baruönü), Deliha (2014, Hakan Algül) gibi Türk sinemasının en çok izlenen ilk 100 filmi arasında yer alıp çalışmamızın asıl odak noktasını oluşturan komedi film örneklerinin tamamında şiddet öğesine yer verilmektedir. Özelikle Cem Yılmaz, Şahan Gökbakar gibi komedyenlerin filmlerinde küfürler, el şakaları ile şiddet komedi unsuru olarak sunulmaktadır.

\section{Yöntem}

Yeşilçam sonrası Türkiye'de sinema üretiminin azalması 2000'li yıllara kadar devam etmiş, durgun geçen dönemin ardından bu yıllardan itibaren gerek nicelik gerekse nitelik açısından üretim artmıştır. Komedi filmleri de bu gelişmelerden etkilenerek en çok film üretimi gerçekleştirilen türler arasında yer almıştır.

Türkiye'de komedi filmleri-şiddet olgusu ilişkisini ve komedi filmlerinin şiddet unsurlarını ne oranda perdeye yansıttığını ortaya koymak amacıyla yapılan bu çalışmada içerik analizi yöntemi kullanılmıştır. İzleyici sayıları baz alınarak en çok izlenen ilk 20 film içindeki komedi filmleri tespit edilmiş ve bu filmler araştırmanın örneklemini oluşturmuştur. Oluşturulan kategori formu doğrultusunda teorik çerçevede altı çizilen unsurların filmlerdeki yansımaları tespit edilmeye çalışılmıştır. Öncelikle filmlerin şiddete yer verip vermediği, bu şiddetin bireysel mi kolektif mi olduğu, şiddetin faillinin cinsiyete göre dağılımı, şiddetin türü, ekrana nasıl yansıdığı gibi unsurlara cevap aranmış ardından filmin içeriği ve şiddetin işlevi filmler üzerinden değerlendirilmiştir.

Türkiye'de en çok izlenen filmlere bakıldığında komedi filmlerin tür olarak daha çok tercih edildiği görülmektedir. Türk sinema tarihinin en çok izlenen 20 filminin 13'ünün komedi türünde olduğu görülmektedir.

Tablo 1: Türkiye'de En Çok İzlenen İlk 20 Film

\begin{tabular}{|l|l|c|c|}
\hline & Filmin Adı & Gösterim Tarihi & İzleyici Sayısı \\
\hline $\mathbf{1}$ & Recep İvedik 5 & 16.02 .2017 & 7.437 .050 \\
\hline $\mathbf{2}$ & Recep İvedik 4 & 21.02 .2014 & 7.369 .098 \\
\hline $\mathbf{3}$ & Düğün Dernek & 06.12 .2013 & 6.980 .070 \\
\hline $\mathbf{4}$ & Fetih 1453 & 16.02 .2012 & 6.572 .618 \\
\hline $\mathbf{5}$ & Müslüm & 26.10 .2018 & 6.474 .497 \\
\hline $\mathbf{6}$ & Düğün Dernek 2: Sünnet & 04.12 .2015 & 6.073 .364 \\
\hline $\mathbf{7}$ & Ayla & 27.10 .2017 & 5.589 .872 \\
\hline $\mathbf{8}$ & Aile Arasında & 01.12 .2017 & 5.289 .051 \\
\hline $\mathbf{9}$ & Arif v 216 & 05.01 .2018 & 4.968 .462 \\
\hline $\mathbf{1 0}$ & Recep İvedik 2 & 13.02 .2009 & 4.333 .144 \\
\hline $\mathbf{1 1}$ & Recep İvedik & 22.02 .2008 & 4.301 .693 \\
\hline $\mathbf{1 2}$ & Kurtlar Vadisi: Irak & 03.02 .2006 & 4.256 .567 \\
\hline $\mathbf{1 3}$ & Ailecek Şaşkınız & 02.03 .2018 & 4.034 .858 \\
\hline
\end{tabular}




\begin{tabular}{|l|l|c|c|}
\hline 14 & G.O.R.A. & 12.11 .2004 & 4.001 .711 \\
\hline 15 & Eyyvah Eyvah 2 & 07.01 .2011 & 3.947 .988 \\
\hline 16 & $\begin{array}{l}\text { CM101MMXI } \\
\text { Fundamentals }\end{array}$ & 03.01 .2013 & 3.842 .535 \\
\hline 17 & Babam ve Oğlum & 18.11 .2005 & 3.839 .883 \\
\hline 18 & Mucize (2015) & 01.01 .2015 & 3.737 .605 \\
\hline 19 & A.R.O.G & 05.12 .2008 & 3.707 .086 \\
\hline $\mathbf{2 0}$ & Dağ 2 & 04.11 .2016 & 3.600 .000 \\
\hline
\end{tabular}

Kaynak: https://boxofficeturkiye.com/, Erişim Tarihi: 01.11.20194

Çalışmamız komedi filmlerine odaklandığından dolayı, ilk 20 film içerisinde yer alan Fetih 1453, Müslüm, Ayla, Kurtlar Vadisi Irak, Babam ve Oğlum, Mucize ve Dağ 2 filmleri analiz dışında tutulmuştur. Bunun yanı sıra listede 18. Sırada yer alan ve Cem Yılmaz'ın bir stand up gösterisinden oluşan CM101MMXI Fundamentals kurmaca bir öykü anlatmadığı ve farklı bir formatta görüldüğü için incelemeye alınmamıştır. Bunun dışında yer alan 12 film ise çalışmamızın örneklemini oluşturmaktadır. Bu kapsamda ele alınan 4 film Recep İvedik serisine ait filmlerden oluşurken, Düğün Dernek serisi de 2 filmle en çok izlenenler arasında bulunmaktadır. Ayrıca Cem Yılmaz'ın başrolünde oynadığı ve Arif karakterine ilişkin öykülerin anlatıldığı G.O.R.A., A.R.O.G. ve Arif V 216 filmleri de seri filmler olarak değerlendirilebilir. Filmler aynı ana karakterler üzerinden şekillense de farklı öyküler anlattığı için ayrı ayrı ele alınmaktadır.

\section{Bulgular}

Ele alınan filmler öncelikle şiddetin türlerine göre dağılımı açısından incelenmiş ve her filmde kaç adet bu öğelerin yer aldığı tespit edilmiştir. Tablo 2'de bu rakamlar ayrıntılı olarak yer almaktadır.

Tablo 2: Şiddetin Türlerine Göre Dağılım

\begin{tabular}{|l|c|c|c|c|c|c|}
\hline Filmler & Fiziksel & Sözel & Duygusal & Cinsel & Ekonomik & Toplam \\
\hline Aile Arasında & 28 & 69 & 8 & - & 3 & 108 \\
\hline Ailecek Şaşkınız & 10 & 8 & 4 & 1 & 3 & 26 \\
\hline Arif v 216 & 46 & 60 & 10 & 2 & 3 & 121 \\
\hline A.R.O.G. & 32 & 33 & 15 & 4 & - & 84 \\
\hline Düğün Dernek & 30 & 48 & 15 & 7 & 6 & 106 \\
\hline $\begin{array}{l}\text { Düğün Dernek 2: } \\
\text { Sünnet }\end{array}$ & 31 & 33 & 11 & 5 & 13 & 93 \\
\hline Eyvah Eyvah 2 & 15 & 33 & 7 & - & - & 55 \\
\hline G.O.R.A. & 44 & 43 & 7 & 15 & 1 & 110 \\
\hline Recep İvedik & 18 & 75 & 5 & 29 & 3 & 130 \\
\hline
\end{tabular}

4 Filmlerin gişe rakamlarına dair veriler, araştırmanın gerçekleştirilmeye başlandığı Kasım 2019 tarihinde boxofficeturkiye.com adresinden elde edilmiştir ve gişe rakamları baz alınarak oluşturulmuştur. Araştırma Kasım 2019 tarihine kadar geçerli olan veriler üzerinden gerçekleştirilmiştir. 


\begin{tabular}{|l|c|c|c|c|c|c|}
\hline Recep İvedik 2 & 31 & 108 & 18 & 17 & 2 & 176 \\
\hline Recep İvedik 4 & 27 & 58 & 22 & 15 & 2 & 124 \\
\hline Recep İvedik 5 & 50 & 77 & 21 & 15 & 3 & 166 \\
\hline TOPLAM & 362 & 645 & 143 & 110 & 39 & $\mathbf{1 2 9 9}$ \\
\hline
\end{tabular}

Tablo 2'de de görüldüğü üzere en çok şiddet öğesinin yer aldığı film 176 şiddet unsuru ile Recep ivedik 2 filmi olmuştur. 12 filmde toplamda 1299 adet şiddet öğesine rastlanmıştır.

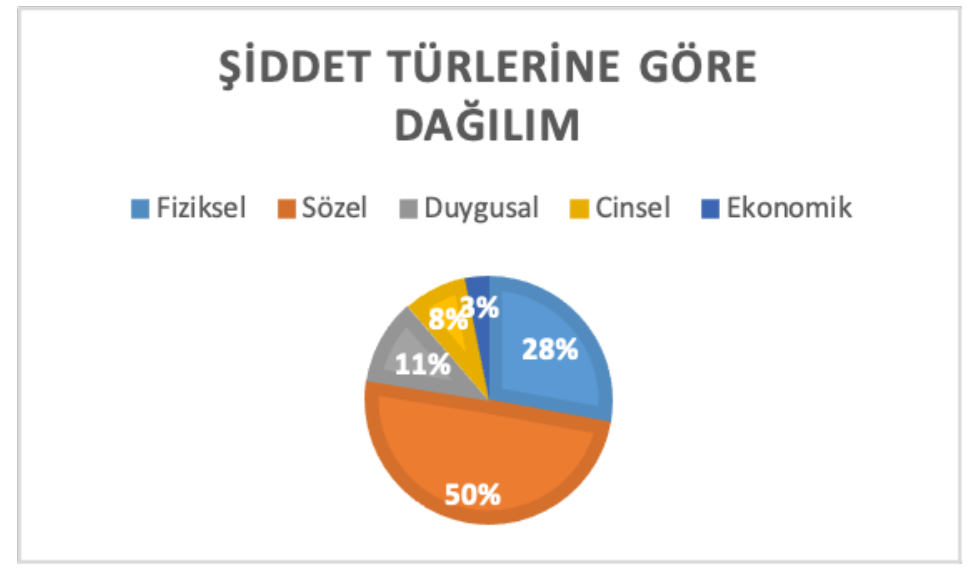

Şekil 1: Şiddet Türlerine Göre Dağılım Oranları

Şekil 2'de yer alan oranlara bakıldığında, en çok karşılaşılan şiddet türü \%50 oranla sözel şiddettir. Ardından \%28 oranla fiziksel şiddet gelirken en düşük oran \%3 ile ekonomik şiddettir.

Gerçekleşen şiddetin bireysel mi kolektif mi olduğuna bakıldığında bireysel şiddetin çok daha fazla gerçekleştiği görülmektedir.

\section{Şiddetin Kaynağı}

\section{$2 \%$}

$98 \%$

Bireysel

Kolektif

Şekil 2: Şiddetin Kaynağının Dağılım Oranları 
Kolektif şiddet filmlerin tamamında sadece \%2 oranında görülürken, bireysel şiddet \%98 oranında görülmektedir.

Tablo 3: Filmlerde Şiddetin Kaynağı

\begin{tabular}{|l|c|c|}
\hline Filmler & Bireysel & Kolektif \\
\hline Aile Arasında & 106 & 2 \\
\hline Ailecek Şaşkınız & 25 & 1 \\
\hline Arif v 216 & 115 & 6 \\
\hline A.R.O.G. & 82 & 2 \\
\hline Düğün Dernek & 99 & 7 \\
\hline Düğün Dernek 2: Sünnet & 91 & 2 \\
\hline Eyvah Eyvah 2 & 54 & 1 \\
\hline G.O.R.A. & 104 & 6 \\
\hline Recep İvedik & 128 & 2 \\
\hline Recep İvedik 2 & 175 & 1 \\
\hline Recep İvedik 4 & 123 & 1 \\
\hline Recep İvedik 5 & 165 & 1 \\
\hline TOPLAM & 1267 & 32 \\
\hline
\end{tabular}

Ele alınan 12 film içinde çoğunlukla bireysel şiddet eylemleri görülürken Düğün Dernek filmi en fazla kolektif şiddet eyleminin görüldüğü film olma özelliği göstermektedir. Toplamda görülen 7 kolektif şiddet eylemi içinde hem fiziksel şiddet hem de karşı tarafı baskı altına alıp istediği davranışı yaptırmak için uygulanan duygusal şiddet eylemleri bulunmaktadır. Ancak kolektif şiddet eylemleri içinde fiziksel şiddetin en baskın şekilde yer aldığı film Arif V 216 filmidir. Filmde önce mahallelinin 216’yı mahalleden atmak için Arif'in evinin önünde gerçekleştirdiği eylem ardından ajanların, polislerin, askerlerin mahalleye baskın yapması ve silah kullanmaları daha çok aksiyon-macera filmlerinde görülen sahneleri andıran şiddet içeriğini andırmaktadır.

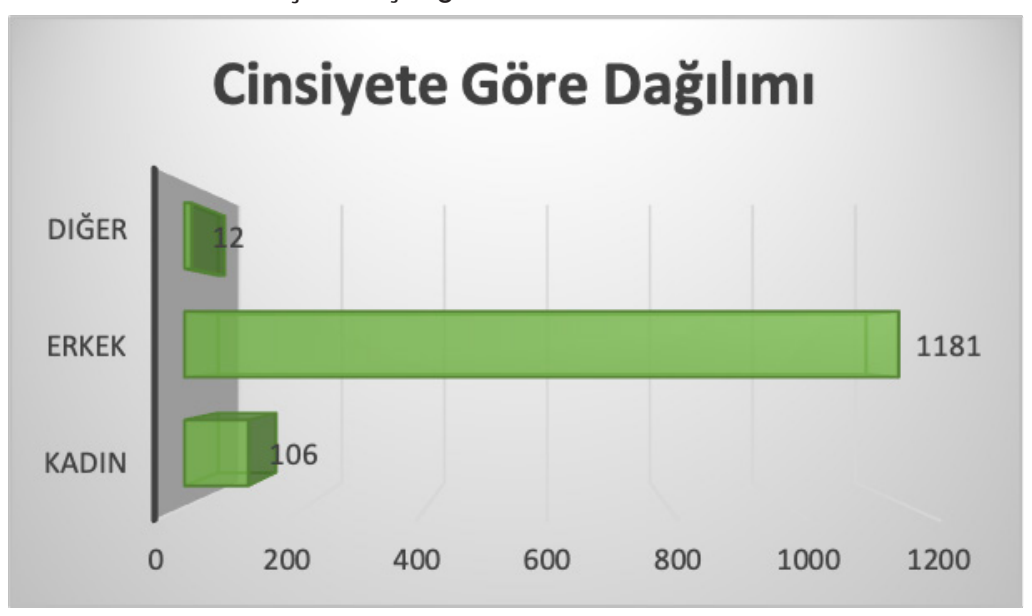

Şekil 3: Şiddetin Kaynağının Cinsiyete Göre Dağılım Oranları 
Şiddetin failine cinsiyet açısından bakıldığında, grafikte görüldüğü gibi, erkek şiddetinin kadınlara göre çok daha fazla olduğu ortaya çıkmaktadır. Toplamda 1181 erkek şiddeti yer alırken kadın şiddeti 106'dır. Şiddetin failinin kadın olduğu eylemlerin filmlere göre dağılımına bakıldığında ise Aile Arasında filminde eylemlerin 27'si kadın karakterler tarafından gerçekleştirilirken, Eyvah Eyvah'ta 10'u, Ailecek Şaşkınız'da 1'i, Düğün Dernek'te 4'ü, Düğün Dernek 2: Sünnet'te 9'u, Arif V 216'da 7'si, G.O.R.A.'da 6'sı, A.R.O.G.'ta 6'sı Recep Ivedik'te 10'u, Recep Ivedik 2'de, 21'i Recep ivedik 4'te 3'ü, Recep Ivedik 5 te 2'si, kadın karakterler tarafından gerçekleştirilmiştir. Aile Arasında 27 şiddet eylemi ile kadın karakterlerin en çok şiddet gösterdiği filmdir. Filmde yer alan ve Taksim'de sahnelerde vokal yaparak hayatını kazanan Solmaz karakterinin bu oranda etkisi büyüktür. Solmaz'ın sürekli küfürlü konuşan yapısı ve fiziksel şiddete eğilimli hali bu oranı yükseltmektedir. Bunun dışında Arif V 216 ile G.O.R.A.'da yer alan robot $216^{5}$ 'da G.O.R.A.'da 4, Arif $V 216^{\prime}$ da 8 şiddet eylemi göstermiştir.

Filmler içinde sadece kişilere karşı değil çevreye ve hayvanlara karşı şiddet eylemlerine rastlanılmaktadır. Aile Arasında filminde 4'ü çevreye, Eyvah Eyvah'ta 1'i hayvana, Düğün Dernek'te 2'si çevreye, Dügün Dernek 2: Sünnet'te 3'ü çevreye, Arif V 216'da 3'ü çevreye, G.O.R.A.'da 4'ü çevreye, A.R.O.G.'ta 1'i çevreye, 1'i hayvana, Recep Ivedik'te 2'si çevreye, Recep İvedik 2'de 2'si çevreye, 1'i hayvana, Recep Ivedik 4'te 2'si çevreye, olmak üzere toplamda 26'sı çevreye, 3'ü hayvanlara karşı şiddet eylemi gerçekleşmiştir. Çevreye uygulanan şiddet kapı-cam kırma, eşyaları dağıtma vurma, etrafı yakma, yıkma, çevreyi kirletme şeklinde gerçekleşirken, hayvana uygulanan şiddet hayvana vurma, tecavüz, hayvanların uyguladığı şiddet ise ısırma şeklinde gerçekleşmiştir.

Şiddet içerikli unsurların nasıl veriliğine bakıldığında; Aile Arasında, Eyvah Eyvah, Ailecek Şaşkınız, Arif V 216, Recep İvedik 2, Recep İvedik 4 ve Recep İvedik 5 filmlerinde şiddet sahnelerinin tamamının hem görsel hem de işitsel olarak birlikte sunulduğu görülmektedir. Bu sahnelerde kimi zaman şiddet doğrudan ya da kimi durumlarda şiddetin mağduru, faili ya da sonuçları ile izleyiciye gösterilmiştir. Diğer filmlerde ise şiddetin hem görsel hem işitsel yer aldığı sahnelerin yanı sıra sadece işitsel şiddet sahneleri de yer almaktadır. Bu durumda, izleyici olayı karakterlerin anlattıklarından öğrenmekte veya sahnelerin kapanışı ya da açılışı sırasında izleyiciye şiddet sahnesinin gerçekleştiği hissettirilmektedir. Bu tür sahnelere Recep İvedik'te 1, G.O.R.A.'da 1, A.R.O.G.'ta 1, Düğün Dernek'te 2 ve Düğün Denek 2: Sünnet’te 1 kez olmak üzere toplamda 6 defa rastlanmaktadır.

Genel bir değerlendirme yapıldığında, Türk sinema tarihinin en çok izlenen 12 komedi filminde gerek, sözel, gerek duygusal gerekse fiziksel ve cinsel şiddettin yoğun olarak kullanıldığı görülmektedir. Adam öldürmeden, tecavüze, hakaretten, küçük düşürmeye kadar hemen her unsurun yer aldığı filmlerde el şakaları, cinsel içerikli hareketler ve küfür komedi unsuru haline gelmekte, bireysel erkek şiddetinin baskın oranda yüksek olduğu dikkat çekmektedir. 


\subsection{Film İçerikleri ve Șiddetin Sunumu}

Incelenen filmler içinde şiddet içeriğine en çok yer veren filmler 176 öğe ile Recep Ivedik 2 filmi, ardından 166 öğe ile Recep ivedik 5 filmidir. Şahan Gökbakar'ın ilk olarak 2005 yılında ekrana gelen Dikkat Şahan Çıkabilir programında yer alan ve bir televizyon programı karakteri olarak doğan Recep İvedik'in maceraları 2008 yılında beyazperdeye taşınmış ve izleyicinin yoğun ilgisi sonucu 2019 yılının sonunda 6.'sı vizyona girmiştir. İlk filmde Recep'in çocukluk aşkı Sibel ile tesadüfler sonucu yıllar sonra karşılaşması, ikinci filmde Recep'in ninesi Pakize'nin ölmeden önce Recep'in iş bulup sonra da evlenmesi için onu zorlaması sonucu yaşadıkları, dördüncü filmde izleyicilerin televizyon ekranlarından aşina olduğu ve çok izlenen "adada hayatta kalma" formatı yarışmaya katılması, beşinci filmde Türkiye spor kafilesini Avrupa'ya yarışma götürmesi ve yaşananlar yüzünden kendisinin yarışmacı olması anlatılmaktadır.

İlk filmde 104, 2. sinde142 şiddet eyleminin faili Recep iken, 2. filmde yer alan babaanne karakteri ise 19 şiddet eylemi gerçekleştirmiştir. Recep karakterine çok benzeyen babaanne karakteri de tıpkı Recep gibi sürekli küfürlü konuşmakta, hakaret etmekte ve zaman zaman fiziksel şiddet göstermektedir. 4. filmde yer alan 124 şiddet eyleminin 7'si hariç tamamı Recep karakteri tarafından gerçekleştirilmiştir. 5. filmde 166 eylemin 138'inde şiddet eyleminin faili Recep karakteridir.

Faili Recep olan ve doğrudan görsel ve işitsel olarak gösterilen şiddet eylemlerine bakıldığında dövme, el kol hareketleri, tükürme, herhangi bir cisim fırlatma, bağırma, hakaret, küfür, tehdit, fiziksel özelliklerle dalga geçme ve aşağılama, mobing, karşı tarafın konuşmasına izin vermeme, taciz ve cinsel içerikli sözler, şakalar gibi öğelerden oluşmakta ve bu unsurların Recep karakterinin süreklilik haline gelen davranışları olduğu görülmektedir. Recep'in homofobik tutumu ve eşcinsel kamyon şoförü ile aralarında geçen diyalog da bir şiddet unsuru olarak filmde yer almakta ve Recep'in eşcinselleri aşağılayan tavrı ve hareketleri de bir mizah öğesi haline getirilmektedir.

Filmde yer alan şiddet eylemlerinin çok büyük bir kısmının, olay örgüsünün ilerleyişinde etkisi bulunmamakta ve Recep karakterinin sıradan davranışları olarak sunulmaktadır. Bu durum şiddet eylemlerinin temel işlevinin mizah olduğu sonucunu ortaya çıkarmaktadır. Recep karakterini tanımlayan ve abartılarak karikatürize edilen bu davranışlar olay örgüsünden çok izleyicilerin gülmesine yönelik olarak oluşturulmaktadır.

Daha önce de belirttiğimiz gibi televizyon programı skeçlerinde doğan karakterin sadece maceraları değil anlatımda ki bu parçalı yapı da beyazperdeye taşınmıştır. Genel olarak öykü anlatmaktan çok Recep'in yaptıkları üzerine odaklanan filmlerde izleyici bu parçalı yapı ile karşı karşıya kalmıştır. Örneğin 4. filmin seyircinin doğrudan aşina olduğu ve izlenme oranlarının yüksek olduğu "adada hayatta kalma formatlı yarışma" programı şeklinde çekilmiş olması, seyircinin zaten her gün karşılaştığı görsel anlatı diliyle sinemada karşılaşması filmin izlenebilir ve anlaşılır olmasını izleyici açısından kolaylaştırmaktadır (Kııç, 2018, 335). Kılıç'ın Recep İvedik izleyicileri üzerine yaptığı alımlama araştırmasında ortaya koyduğu gibi Recep İvedik karakterinin "kaba" olduğu ve "iğrenç" hissi uyandırdığı hemen hemen her katıımcının açıklamasında belirtilmiş, 
insanların fiziksel özellikleri ile dalga geçmesi kırıcı bulunmuş ancak tüm bunlara rağmen davranışları komik olarak nitelendirilerek, karakterin "açık sözlü" olduğu üzerinde ortak kanı oluşmuş ve gerçek hayatta da bu kadar açık sözlü olabilme isteği katılımcılar tarafından belirtilmiştir (Kılıç, 2018).

Olaylar arasındaki neden-sonuç ilişkisi yokluğu ve bu parçalı yapı, filmlerde yer alan şiddet eylemlerinin tamamına yakınının sadece komedi unsuru olarak yer almasına neden olmaktadır. Recep İvedik karakterinin izleyciler tarafından "açık sözlü" bulunan karakterinin günlük hayatta da kimi zaman özenilen bir durum haline geldiği söylenebilmektedir.

En çok izlenen komedi filmleri arasında yer alan ve bir karakterin yaşadıkları üzerine odaklanan ikinci seri ise Cem Yılmaz'ın canlandırdığı Arif karakteri üzerinedir. "Bir uzay macerası" olarak sunulan ilk film G.O.R.A., askeri birlik tarafından kaçırılan Arif'in başka bir gezegende yaşadıkları ve dünyaya dönmek için yaptıklarını anlatmaktadır. Kaçırılma eylemi ile başlayan şiddet sahneleri öldürme, dövme, istemediği davranışa zorlama, küfür, hakaret, bağırma, tehdit, aşağılama, tecavüz, cinsel içerikli şakalar ve el şakaları ile devam etmektedir. Filmde yer alan ilk önemli şiddet eylemi Arif'in kaçırılması olarak görülmekte, çünkü bu durum filmde gerçekleşen olayların da nedenini oluşturmaktadır.

Ele alınan filmler arasında cinsel bir şiddet eylemi olan tecavüz sahnesine sadece G.O.R.A. filminde yer verilmekte ve G.O.R.A. askeri birliğinin komutanı Logar'ın, Dünyalılara olan nefretinin nedeni olarak bu olay gösterilmektedir. Dünya'ya giden Komutan Kubar, bir insan tarafından kovalanmakta ve robotuna tecavüz edilmektedir. Yaşanan bu olay Logar'ın öç almaya yönelik davranışlarının nedenini oluşturmakta dünyalıları kaçırıp köle olarak kullanmaktadır.

İkinci film olan A.R.O.G.'ta Ceku ile evlenip dünyaya dönen Arif'in arkasından gelen Komutan Logar'ın Arifi bir zaman makinesi ile yontma taş devrine göndermesi sonucu orada yaşadıkları ve geri dönme çabaları anlatılmaktadır. Bu filmde de G.O.R.A.'da olduğu gibi dövme, zorlama, küfür, hakaret, bağırma, tehdit, aşağılama, tecavüz, cinsel içerikli şakalar ve el şakaları gibi pek çok fiziksel, duygusal ve sözel şiddet unsuruna rastlanmaktadır. G.O.R.A. da tecavüz sahnesine yer verilip bu durum izleyiciye gösterilirken A.R.O.G.'ta bu sahne izleyiciye hissettirilerek aktarılmıştır.

Arif'in ana karakter olarak yer aldığı üçüncü film ise Arif $V 216$ 'dır. Arif'in G.O.R.A. gezegeninde tanıştığı ve arkadaş olduğu robot 216'nın dünyaya gelmesi ve insan olup Yeşilçam filmlerinde izlediği aşkı yaşamak istemesiyle başlayan filmde olaylar yine şiddet sahneleri ile başlamaktadır. 126'yı mahallede istemeyen insanların protestoları ve eylemlerinin ardından ajanların, askerlerin mahalleyi basması ve 216 'yı ele geçirmeye çalışması ile Arif ve 216'nın zaman makinesini kullanarak geçmişe dönmesi ile öykü başlamaktadır. Bu filmde de kavga, ateş etme, bayıltma, kaçırma, küfür, hakaret, tehdit, aşağılama, istemediği davranışa zorlama gibi pek çok şiddet unsuru yer almaktadır.

Recep İvedik serisine göre parçalı anlatımdan daha uzak olan ve neden-sonuç ilişkisi 
bağlamında olay akışı sağlayan her üç filmde de çok sayıda şiddet içerikli davranış yer almaktadır. G.O.R.A.'da 110 şiddet içerikli davranış yer alırken, A.R.O.G.'ta 84, Arif $V 216^{\prime}$ da bu sayı $121^{\prime}$ 'dir. Kendi içinde bir konu bütünlüğü olmasına rağmen şiddet eylemlerinin büyük bir bölümü Recep İvedik serisinde olduğu gibi komedi unsuru olarak yer almaktadır. Gülünç duruma düşürücü, küfürlü ifadeler sıkça kullanılmakta, özellikle Arif karakterinin iğneleyici ve küfürlü ifadeleri çokça kullanması hem karakterin özellikleri hakkında bilgi vermekte hem seyirciyi güldürme amacı taşımaktadır. Arif $V$ 216 filminde ana karakterlerden biri olarak karşımıza çıkan robot 216 'da hem şiddet görmekte hem de şiddetin faili olmaktadır. Genel olarak filmlerde yer alan karakterlerin tamamı abartılarak komedi öğesi haline getirilmiştir.

Tıpkı Recep İvedik filminde olduğu gibi G.O.R.A. filminde de eşcinselliğe gönderme bulunmakta ve filmin kötü karakteri ve yardımcısının gerçekte bir eşcinsel olduğu ve bunu gizlediği ima edilerek, kötü olarak sunulan ve acımasızca şiddet gösteren Logar ve yardımcısının cinsel tercihleri de homofobik bir tavırla izleyiciye sunulmaktadır ve bu durum da bir komedi unsuru haline getirilmiştir.

İzlenen 12 film içinde ki tek tecavüz sahnesine sahip olan G.O.R.A. filminde bu sahne dahi her ne kadar neden-sonuç ilişkisi bağlamında aktarılsa da bir komedi unsuru olarak sunulmuştur. Geçmişin hatırlanma şekli, kullanılan renkler, hızlandırılmış sahne ve kullanılan müzik ile hızlıca geçmişe dönen karakter olayı izleyiciye aktarmakta ve sahne en ileri seviyedeki cinsel şiddet eyleminin içeriğini, travmayı ve sonucunu izleyiciye aktarmaktan uzak olarak perdeye yansıtılmakta ve olay mizah unsuru haline getirilmektedir. G.O.R.A.'da robota insan tarafından gerçekleştirilen tecavüz eylemi izleyiciye mizansen şeklinde gösterilerken, A.R.O.G.'ta tecavüz sahnesi görsel olarak izleyiciye gösterilmemiştir. Ancak Arif karakterinin bir maymunla ilişkiye girdiği gerek hemen sonrasında gelen sahnede gerekse ilerleyen sahnelerde izleyiciye hissettirilmiştir. Maymunla gecenin ilerleyen saatinde ele ele karanlığa karışan Arif'in hayvana tecavüzü sanki iki kişinin normal bir cinsel birlikteliği olarak aktarılmış ve Arif'in "çok zor durumdaydım", "bu olayı konuşmak istemiyorum" gibi söylemleri ve maymunun olayın ardından Arif'in arkasından dolaşması hayvana gerçekleşen bir tecavüzden çok iki insanın ilişkisi şeklinde aktarılmakta ve normalleştirilmektedir. Arif'in yaşadığı bu olay film içinde karikatürize edilerek, komedi unsuruna dönüşmektedir. Bireyin bedensel bütünlüğüne yapılan en ağır şiddet eylemi olarak kabul edilebilecek olan tecavüzün iki filmde de bağlamından koparılıp komedi unsuru haline getirilmesi, cinsel şiddet karşısında duyarsızlaşmayı artırmaktadır.

Dügün Dernek de tıpkı önceki filmler gibi izleyiciden gördüğü ilgi sonucu devamı çekilen seri filmler arasında yer almaktadır. 2013 yılında çekilen ilk film Düğün Dernek'in ardından ikinci film Düğün Dernek 2: Sünnet 2015 yılında gösterime girmiştir. Ahmet Kural, Murat Cemcir, Rasim Özetkin, Devrim Yakut, Barış Yıldız ve Şinasi Yurtsever'in canlandırdığı ana karakterlerin aynı olduğu filmlerin ilkinde oğlunu evlendirmek isteyen ve bunun için para bulup düğün yapmaya çalışan İsmail ve arkadaşlarının ikinci filmde de torununu sünnet ettirebilmek için neler yaptıkları hikayenin ana konusunu oluşturmaktadır.

İlk filmde 106 şiddet eylemi yer alırken ikinci filmde 94 şiddet eylemi bulunmaktadır. 
Karakterlerin küfür içeren söylemleri aşağılama, kişilerin fiziksel özellikleri ile dalga geçme sıklıkla yer almaktadır. Bunun yanı sıra diğer filmlerden farklı olarak filmde yer alan Yılmaz karakterinin bir parçası haline gelen hırsızlık ve dolandırıcılık olayları da komedi unsuru olarak kullanılmaktadır. En yakın arkadaşlarının bile paralarını, eşyalarını çalması herhangi bir tepki görmemesi ve bu durumun onun karakteri ile özdeşleştirilerek sunulması komedi unsurunun bir parçası olarak algılanmasına neden olmaktadır. Dügün Dernek 2: Sünnet filmi bu anlamda ekonomik şiddetin en çok kullanıldığı film olma özelliği taşımaktadır. Yine Düğün Dernek 2: Sünnet filminde yer alan ve çocuğu sünnet ettirebilmek için gerek aileye gerek çocuğa yapılan baskı da duygusal şiddetin en net şekilde görüldüğü örnekler arasında yer alır.

Murat Cemcir ve Ahmet Kural ikilisinin rol aldığı Ailecek Şaşkınız filmi de en çok izlenen komedi filmleri arasında yer almakta ve 26 şiddet eylemi ile incelenen filmler arasında en az şiddet içeriğine sahip film olarak karşımıza çıkmaktadır. İkilinin geçmişte birlikte yaptıkları gerek televizyon gerekse de sinema için filmler göz önünde tutulduğunda izleyicinin beklentisi de komedi yönünde olmakta ve özellikle birlikte yer aldıkları sahnelerde komedi unsuru ön plana çıkmaktadır. Filmde olaylar gerek duygusal, gerek fiziksel gerekse de sözel açıdan yer alan şiddet sahneleriyle başlamasına rağmen olayların ilerlemesi ile bu eylemler azalmakta ve film romantik komedi türüne kayarak izleyici Ferhat'ın Elif'i elde etmek için yaptıklarını izlemeye başlamaktadır. Ancak bu romantik aşk hikayesinde de özellikle Ferhat karakterinin şirket çalışanlarına uyguladığı mobing ağırlıklı olarak yer almaktadır. Elif'in ablasının eski kocası ve Ferhat arasında ve komiser olan Elif ile hırsız arasında geçen kavga sahnesi de fiziksel şiddetin en yoğun yaşandığı sahneler arasında yer alır. Eski eşin boksör olması ve Ferhat'ın ondan dayak yemesi sahnesi karikatürize edilerek verilir. Ferhat'ın yediği her tokat ya da yumruğun ardından yaptıkları, söyledikleri, jestleri ve mimikleri fiziksel şiddet mağdurunun hal ve hareketlerinden tamamen uzaktır ve bir komedi unsuru olarak filmde yer alır. Elif'in Ferhat'ın evine giren hırsızla olan kavga sahnesinde de, Elif'in yaptığı her bir hareket, Ferhat'ın ona aşık olması ve geleceğe dair hayaller eşliğinde sunulmaktadır. Böylece fiziksel şiddetin yoğun olarak yaşandığı bu iki sahnede abartılıp, karikatürize edilerek içeriği boşaltılmış ve komedi unsuru haline getirilmiş olur.

Gülse Birsel'in senaryosunu yazdığı ve Engin Günaydın ile Demet Evgar'ın başrollerini üstlendiği Aile Arasında filmi de en çok izlenen ve aynı zamanda en çok şiddet eyleminin yer aldığı filmler arasında yer almaktadır. Tek başına bir öykü barındırması ve devam filmi olmaması ile diğer filmlerden ayrılan film, boşanmak üzere olan ve evden ayrılan Fikret'in, sevgilisi tarafından terk edilen Solmaz ile tanışması ile başlamaktadır. Olayların başlamasına neden olan bu ilk tanışma sahnesi de dahil olmak üzere film toplamda 108 şiddet eylemi içermektedir. Kavga, silah çekme, yaralama, tehdit, küfür, hakaret, aşağılama, zorlama gibi șiddet unsurlarının sıklıkla uygulandığı görülmektedir. Diğer filmlerden farklı olarak filmde kadın karakterler şiddetin faili olarak daha fazla yer almaktadır. 108 eylemin 26'sı kadın karakterler tarafından gerçekleştirilmiştir. Özellikle filmin ana karakterlerinden olan Solmaz'ın sürekli küfürlü konuşması, fiziksel şiddete yatkın olması ve uygulaması onun karakter özelliği olarak sunulmakta ve yaptıkları izleyici açısından da normalleşmektedir. Fikret ve Solmaz'ın ilk karşılaştıkları sahnede yanlış anlamalar sonucu Solmaz'ın Fikret'e hem sözel hem de fiziksel 
şiddet uygulaması sonrasında Solmaz'ın yaptıkları Fikret tarafından bile hoşgörüyle karşılanmış ve izleyiciler için şiddet eylemleri bir komedi unsuru olmuştur.

Adanalı bir aile olan Karadağ ailesinin yaşadığı mafyatik ilişkiler, sürekli silahların çekilmesi de normalleştirilen ve komedi unsurunun bir parçası haline gelen öğeler arasında yer almaktadır.

Değerlendirmeye dahil olan son film Eyvah Eyvah 2 ise Ata Demirer ve Demet Akbağ'ın başrollerini paylaştıkları seri filmin ikincisidir. Öncesinde ve sonrasında çekilen 2 filmde $^{6}$ izleyici tarafından ilgi görmüş ancak sadece 2. film en çok izlenen 20 film listesinde yer almıştır. Ana karakterleri Hüseyin ve Firuzan olan Eyvah Eyvah filmlerinin 2.sinde Hüseyin'in çok sevdiği Müjgan'a duygularını anlatmaya çalışması ve Müjgan'ın ailesinin bu ilişkiye karşı çıkması anlatılmaktadır. Dayaktan, insan kaçakçılığına, bayıltma ve silah çekmeden, küfür, hakaret, aşağılama ve fiziksel özellikleri dolayısıyla dalga geçip isim takmaya kadar şiddet içerikli pek çok eylemin yer aldığı film de toplam 57 şiddet içerikli eylem bulunmaktadır. Olayların ve yaşananların neden-sonuç ilişkisi içinde ve belli bir bağlamda verildiği filmde özellikle dalga geçme, isim takma, küfür gibi unsurlar komedi unsuru olarak kullanılmış ve Hüseyin Badem'in gerek başına gelenler gerekse yaptığı şiddet eylemleri onun komik olan karakterinin doğal bir parçası olarak yansıtılmıştır. Örneğin Firuzan karakterinin Hüseyin'e kızması sonucu daha çok aşağılama amacı taşıyarak taktığı "Trakyalı Shrek" ismi de sevimli bir lakap olarak görülmüş ve komedi unsuru olarak kullanılmıştır.

Genel bir değerlendirme yapıldığında, filmlerde, çoğu neden-sonuç ilişkisi bağlamında sunulmasına ya da karakterin tipik özelliği olarak görülmesine rağmen (bazı karakterlerin sürekli küfürlü konuşması gibi) şiddetin çoğunlukla komedi unsuru olarak sunulduğu ve abartılıp karikatürize edilerek verildiği görülmektedir. Tanel Toker’in (2014) "Türk Sinemasında Şiddet: 2002-2012 Yılları Arasında Gişe Hasılatı Yapan Beş Filmdeki Şiddet Öğeleri Üzerine Bir Araştırma" isimli yüksek lisans çalışmasında ortaya koyduğu bulgulara göre, dönemin en çok izlenen ilk beş filmi içinde yer alan ve savaş- çatışma sahnelerinin yoğunlukta olduğu Fetih 1453 ve Kurtlar Vadisi Irak filmlerinin şiddet sahneleri sayı olarak komedi filmlerine yakındır. Fetih 1453 filminde 233 şiddet sahnesi yer alırken, Kurtlar Vadisi Irak filminde 99 şiddet sahnesi yer almaktadır. Şiddet sahneleri içerik ve yer alış bakımından komedi filmlerinden farklılık göstermesine rağmen sayı olarak kimi komedi filmleri aksiyon-macera ve savaş filmi olarak adlandırılabilecek bu filmlerden daha fazla şiddet sahnesine sahiptir. Bu iki filmde adam öldürme, silah çekme, yaralama vb. fiziksel şiddet olayları çok sayıda yer almakta ve çatışmanın getirdiği neden-sonuç bağlamında izleyiciye sunulmaktadır. Oysa komedi filmleri daha çok hissettirmeden, basitleştirip, normalleştirerek bu sahneleri izleyiciye aktarmakta ve özellikle sözel ve duygusal şiddet sahnelerine filmlerde sıklıkla rastlanılmaktadır.

6 Serinin ilk filmi Eyvah Eyvah 2.459.815 kişi tarafından izlenmiş, Türki sinema tarihinin en çok izlenen filmler listesinde 44. sırada yer almıştır. Serinin son filmi olan Eyvah Eyvah 3 ise 3.414 .212 seyirci tarafından izlenerek 25. sırada yer almaktadır. 


\section{Sonuc}

Bir kişiye, kişilere ya da topluluğa yönelik zarar vermeyi amaçlayan her türlü fiziksel, duygusal, sözel saldırı, baskı, tehdit, zorlama gibi maddi manevi unsurlardan oluşan şiddet, insanlığın başından beri her toplumda var olmuş ve günümüze kadar gelmiştir. Günlük hayat içinde sıklıkla yer bulan şiddet, bir süre sonra sinemanın da vazgeçilmez unsurları arasında yer almıştır. Ayırt etmeksizin hemen her tür film içinde bulunan şiddet öğeleri komedi filmleri gibi bireyi eğlendirmeye yönelik filmlerin de vazgeçilmez unsuru olmuştur. Komedi filmlerinde ki vurma, çarpma, kavga, küfür, karakterlerin aşağılayıcı sözleri, komik duruma düşürüp rencide etme gibi söz ve davranışlar normalleştirilerek, mizah unsurları haline gelmiştir.

Türkiye'de en çok izlenen ilk 20 film içindeki komedi filmlerinin içerik analizi yöntemi ile çözümlendiği bu çalışmada, ele alınan filmlerin tamamında şiddet öğelerinin var olduğu tespit edilmiştir. En genel sınıflandırmasıyla fiziksel, sözel, duygusal ve ekonomik şiddet başlıkları ile ayrımladığımız şiddet türlerinin filmlerde ne oranda kullanıldığına bakılmış ve sözel şiddetin en çok kullanılan şiddet türü olduğu bulgusu elde edilmiştir. Adam öldürmeden tecavüze, mobingten tehdide kadar hemen her türde şiddet eyleminin bulunduğu bu filmlerde ayrıca baskın erkek şiddeti dikkat çekmektedir. Faili erkek olan şiddet eylemleri kadın eylemlerine göre çok daha fazladır. İncelenen filmlerin genellikle şiddet unsurlarını hem görsel hem de işitsel olarak perdeye yansıttığı görülmektedir. Bu eylemlerin gösterilmediği durumlarda izleyici karakterlerin olayı anlatması ya da sahnenin açılıp kapanması sonrası yaşananlardan olayın gerçekleştiğini öğrenmektedir. Bireysel şiddetin ön plana çıktığı bu popüler filmlerde şiddet tepki gösterilip cezalandırılmayan, zarara yol açmayan, kavganın küfürün normalize edilip, gerçek ile fantezi arasındaki ayrımın ortadan kalktığı bir öğe olarak yer almaktadır. Özellikle televizyon izleyicisinin beğenisi kazanmış komedyenlerin filmlerinde yer alan sözel, duygusal ve fiziksel şiddet öğeleri bu karakterlerin doğal bir parçası olarak sunulmakta, komedi malzemesi haline getirilmektedir.

\section{Kaynakça}

Abisel, N. (2005). Türk Sineması Üzerine Yazılar. Ankara: Phoenix.

Alemdar, K., Erdoğan, İ. (1994). Popüler Kültür ve Illetişim, Ankara: Ümit Yayıncılık

Aydın Ö. (2012). İfade Özgürlüğüne Vurulmuş Pranga Simgesel Şiddet, Umut Vakfı Hukukun Gençleri Sempozyum Dizisi-3: Hukuk Felsefesi, Antalya, 11-12 Ekim 2012, 1-7. umut.org.tr.

Aziz, A. (1993). Medya, Şiddet Ve Kadın:1993 Yılında Türk Basınında Kadınlara Yönelik Şiddetin Yer Alış Biçimi. Proje Yürütücüsü: Aysel Aziz, Proje Koordinatörleri: Eser Köker, Abdülrezak Altun, Mine Gencel, Nilgün Tutal Küçük. Ankara: Başbakanlık Kadın Ve Sosyal Hizmetler Müsteşarlığı Kadının Statüsü Ve Sorunları Genel Müdürlüğü.

Baudrillard, J. (2004). Tüketim Toplumu. (H. Deliceçaylı ve F. Keskin, Çev), İstanbul: Ayrıntı Yayınları. 
Bourdieu, P., L. J. D. Wacquant. (2003). Düşünümsel Bir Antropoloji için Cevaplar. (Ökten, N. Çev). İstanbul: Iletişim Yayınları.

Browne, N., Webb, T., Fisherr K., Cook, B., McArthur, D., Peek-Asa, C., Kraus, J. (2002). American Film Violence: An Analytic Portrait. Journal Of Interpersonal Violence, Vol.17, No.4, 351-370).

Casique, L., Furegato, A., \& Regina, F. (2006). Violence Against Women: Theoretical Reflections. Revista Latino-Americana de Enfermagem, 14(6), 950-956.

Coker, A. L., Smith, P. H., Mckeown, R. E., \& King, M. J. (2000). Frequency And Correlates Of Intimate Partner Violence By Type: Physical, Sexual, And Psychological Battering. American Journal Of Public Health, 90(4), 553-559.

Dünya Sağlık Örgütü, Şiddet Ve Sağlık Üzerine Dünya Raporu: Özet. Cenaova: WHO, 2002 Https://Www.Who.İnt/Violence_İnjury_Prevention/Violence/World_Report/En/Summary_En.Pdf, Erişim Tarihi 03.10.2019.

Fromm, E. (1994). Sevginin ve Şiddetin Kaynağı. (Salman, Y. ve İçten, N., Çev.). İstanbul: Payel Yayınları.

Gerbner, G., Morgan, M., Signorielli N. (1999). Profiling Television Violence. International Media Monitoring liçinde. S.335-365. New York: Hampton Press.

Jackson, S. M., Cram, F., \& Seymour, F. W. (2000). Violence and sexual coercion in high school students' dating relationships. Journal of family violence, 15(1), 23-36.

Karabağ, ì. (2010). Dil ve Şiddet. İstanbul: İkaros Yayınları

Karayel, B. (2007). Keselim mi Yoksa Besleyelim mi, SinemaTürk, 5, 25-26.

Köse, A., ve Beşer, A. (2007). Kadının Değiştirilebilir Yazgısı "Şiddet". Anadolu Hemşirelik Ve Sağıık Bilimleri Dergisi, 10(4), 114-121.

Leymann, H. (1990). Mobbing And Psychological Terror At Workplaces. Violence And Victims, 5(2), 119-126.

Leymann, H. (1996). The content and development of mobbing at work, European Journal of Work and Organizational Psychology, 5:2, 165-184.

Mcıntosh, W. D., Murray, J. D., Murray, R. M., \& Manian, S. (2003). What's So Funny About A Poke In The Eye? The Prevalence Of Violence In Comedy Films And Its Relation To Social And Economic Threat İn The United States, 1951-2000. Mass Communication And Society, 6(4), 345360.

Mutlu, E. (1997). Televizyon, Çocuklar Ve Şiddet. İstanbul Üniversitesi Iletişim Fakültesi Dergisil Istanbul University Faculty Of Communication Journal, (4). 41-77.

Orta, Nermin (2016). Tecavüzü Seyretmek, Agora Kitaplığı, İstanbul.

Özbulduk Kılıç, I. (2018). Seyirci Deneyiminde Film Tercihini Etkileyen Motivasyonlar ve Filmlerin Alımlanması : Recep İvedik Örneği. TRT Akademi , 3 (5) , 322-343.

Özsöz, C. (2014). Pierre Bourdieu: Simgesel Şiddet, Eğitim, İktidar. Cogito, 74, 290-311.

Pişkin, G. (2007). Hızlı ve Dengesiz Değişime Tepki Olarak Sinemada Şiddet: Türkiye Örneği: 
1980-2006. 38. Icanas-Ankara Türkiye Kültürel Değişim ve Hareketlilik Bildiri Kitapçığı, 573-593.

Retzinger, S. M. (1991). Shame, Anger, And Conflict: Case Study Of Emotional Violence. Journal Of Family Violence, 6(1), 37-59.

Ryan, M., \& Kellner, D. (1997). Politik Kamera. (E. Özsayar, Çev.). İstanbul: Ayrıntı.

Sanatel, K. (2000). Korku-Gerilimde Rönesans, Sinema, Sayı:65, İstanbul

Stossel, S. (1997). The Man Who Counts The Killings. Atlantic Monthly, 279(5), 86-100. Https:// Www.Theatlantic.Com/Magazine/Archive/1997/05/The-Man-Who-Counts-The-Killings/376850/

Toker, T. (2014). Türk Sinemasında Şiddet: 2002-2012 Yılları Arasında Gişe Hasılatı Yapan Beş Filmdeki Şiddet Öğeleri Üzerine Bir Araştırma, Yayınlanmamış Yüksek Lisans Tezi, Anadolu Üniversitesi Sosyal Bilimler Enstitüsü.

Ünlü, A. (2007). Şiddete Gülmek: Geleneksel Türk Tiyatrosunda Şiddet ve Mizah, Tiyatro Araştırmaları Dergisi, Sayı: 24, 27-41.

Ünsal, A. (2007). Genişletilmiş Bir Şiddet Tipolojisi. Cogito, Aylık Düşünce Dergisi, 6-7.

www.boxofficeturkiye.com

Yüce, D. (1995). Sinema İnsanı Tanımaktır, Yeni Yüzyıl Gazetesi, 11 Mayıs 1995.

Zillmann, D. (2000). Humor And Comedy. Media Entertainment: The Psychology Of its Appeal, 37-57.

\section{Extended Abstract}

Violence, which has always existed since the beginning of humanity, has come to the present day by expanding meaning. Today, violence can be defined as physical, emotional and verbal assault, oppression, blocking and material and spiritual harm aimed at harming a person, group, and community. The most widely used classifications of violence are physical, emotional, sexual, economic, verbal, and symbolic violence.

Violence, which is also a part of the narratives, has served as an important element of the story in many works of art, from mythology to cinema. It is often used to increase the dramatic effect and bring the narrative closer to realism. Besides, violence is one of the indispensable elements of action-adventure, western, war, and drama films but it is not limited to only these categories. Distinct aspects of violence are used in different categories from melodrama to comedy. Among the most watched genres such as the comedy and the films aimed at entertaining individuals, violence elements are frequently encountered.

In this study, content analysis method was employed to reveal the relationship between violence and the comedy films made in Turkey and the percentage of the violent elements depicted in each film. The comedy films among the first 20 films that reached the highest number of viewers in Box Office list were selected as a sample. The films were examined based on whether or not violence was included in these films, the source of the violence, the distribution of violence according to gender, the type of violence and how it was depicted on the screen. Then, the content and the function of 
the violence were evaluated through the films.

The study shows that all examined movies contain violent elements. There are a total of 1299 violent acts in 12 films. Verbal violence is the most common type of violence with 50 percent in these movies among physical, verbal, emotional and economic violence. These films include almost all kinds of acts of violence such as murder, rape, mobbing, and threats and the perpetrator of violence is mostly male (1181 out of 1299). In the films, the elements of violence are depicted both visually and audibly. In cases where these actions are not shown, the audience learns the occurrence of the event after the characters talk about it or after the scene opens and closes. Violence is carried out not only against people but also against animals and the environment. In these popular films where individual violence become prominent, violence is an element that is neither reacted nor punished. The fight and swearing are normalized and the violence does not lead to any bad consequences. At this point, the distinction between reality and fantasy disappears. Especially in the movies of comedians who have been admired by the television audience, the elements of verbal, emotional and physical violence are presented as a natural part of these characters and turned into a comedy element.

As a result, it has been found that most of the comedy films contain more elements of violence than other genres and these violence elements are presented as humour elements without showing real consequences of violence. 